\title{
Development and Validation of Stability Indicating RP-HPLC Method for Simultaneous Estimation of Teneligliptin and Metformin
}

\author{
Rajani Vetapalem, Rajendra Prasad Yejella, Lakshmana Rao Atmakuri \\ ${ }^{1}$ Department of Biotechnology, Acharya Nagarjuna University, Nagarjuna Nagar, AP, India \\ ${ }^{2}$ Department of Pharmaceutical Chemistry, University College of Pharmaceutical Sciences, Andhra \\ University, Visakhapatnam, AP, India \\ ${ }^{3}$ Department of Pharmaceutical Analysis, V. V. Institute of Pharmaceutical Sciences, Gudlavalleru, AP, \\ ndia
}

INTRODUCTION: The main objective of the present work was to develop a simple, precise, specific \& stability indicating RP-HPLC method for simultaneous estimation of Teneligliptin and Metformin in bulk and tablet dosage form.

METHODS: The analysis has been performed using Kromasil C18 column $(250$ x $4.6 \mathrm{~mm}, 5 \mu)$ at $30^{\circ} \mathrm{C}$ using buffer: acetonitrile: methanol $(65: 25: 10, \mathrm{v} / \mathrm{v} / \mathrm{v})$ as mobile phase. The detection was carried out at $254 \mathrm{~nm}$ with a flow rate of $1.0 \mathrm{ml} / \mathrm{min}$.

RESULTS: The retention time of Teneligliptin and Metformin was found to be $2.842 \mathrm{~min} \&$ $2.017 \mathrm{~min}$ respectively. The linearity range was $5-30 \mu \mathrm{g} / \mathrm{ml}$ for Teneligliptin and $125-750 \mu \mathrm{g} / \mathrm{ml}$ for Metformin respectively. The forced degradation studies were performed as per the guidelines of ICH under acidic, alkaline, oxidative, thermal, photo stability \& neutral conditions.

DISCUSSION AND CONCLUSION: The developed method was successfully validated for all the parameters and was found to be within the limits. The developed method could be successfully employed for the simultaneous estimation of Teneligliptin and Metformin in bulk and tablet dosage form.

Keywords: Teneligliptin, Metformin, RP-HPLC, Validation, Stability studies.

\section{INTRODUCTION}

Teneligliptin (TEN) (Fig. 1) is chemically [(2S,4S)-4-[4-(5-methyl-2-phenylpyrazol-3yl)piperazin-1-yl]pyrrolidin-2-yl]-(1,3-thiazolidin-3-yl)methanone. It is highly effective in lowering blood glucose levels. This drug inhibits the enzyme dipeptidyl peptidase-4 (DPP4) which degrades incretin, a hormone adjusting blood glucose control. It is effectively used to treat type-II diabetes mellitus ${ }^{1-2}$.

Metformin (MET) (Fig. 2) is chemically 1-carbamimidamido-N,N-dimethylmethanimidamide. It belongs to biguanide class of anti diabetic drugs. It is the first line drug of choice for the treatment of type-II diabetes. It activates AMP-activated protein kinase (AMPK), a liver enzyme 
that plays an important role in insulin signaling, whole body energy balance and metabolism of glucose and fats ${ }^{3-5}$.

Literature survey reveals good number of analytical methods for the estimation of TEN and MET individually or in combination with other drugs using UV spectrophotometry ${ }^{6-8}$, HPLC ${ }^{9-19}$, HPTLC $^{20}$ and LC-MS/MS ${ }^{21}$. Moreover, few methods were reported for the estimation of the selected drugs in their combinations using UV spectrophotometry ${ }^{22-24}, \mathrm{HPLC}^{25-29}$. As per the knowledge of the authors, no stability indicating RP-HPLC method was reported so far for the simultaneous estimation of the Teneligliptin and Metformin. Hence, we tried to develop a simple stability indicating HPLC method for the estimation of selected drugs. The developed method has been validated as per the guidelines of $\mathrm{ICH}^{30}$. To establish stability indicating nature of the method forced degradation studies were planned for the proposed method under acidic, alkaline, oxidative, thermal, photo stability and neutral conditions ${ }^{31}$

\section{EXPERIMENTAL}

\section{Materials \& reagents}

Reference standards of Teneligliptin and Metformin were provided as gift samples by Spectrum Labs, Hyderabad. Commercialiy available tablet formulation Tendia $M$ tablets for the assay studies were purchased from local pharmacy. HPLC grade methanol, HPLC grade acetonitrile, analytical grade ortho phosphoric acid and HPLC grade water were purchased from Merck specialties, Mumbai, India.

\section{Instrumentation}

Development and validation of the method was performed on waters HPLC 2695 system equipped with quaternary pumps, auto sampler \& photo diode array detector. Empower 2 software was applied for data collection and processing. 


\section{Methodology}

\section{Preparation of standard stock solutions}

The standard stock solutions of $200 \mu \mathrm{g} / \mathrm{ml}$ for TEN and $5000 \mu \mathrm{g} / \mathrm{ml}$ for MET were prepared by accurately weighing and transferring $2 \mathrm{mg}$ of TEN and $50 \mathrm{mg}$ of MET into $10 \mathrm{ml}$ volumetric flasks. Added about three fourth of the volume with diluent, sonicated for 10 minutes. Finally flasks were made up to the mark with diluent to obtain the mentioned concentrations. One $\mathrm{ml}$ of the above solution was pipetted out and transferred into a $10 \mathrm{ml}$ volumetric flask and diluted up to the mark with diluent to obtain a concentration of $20 \mu \mathrm{g} / \mathrm{ml}$ for TEN and $500 \mu \mathrm{g} / \mathrm{ml}$ for MET.

\section{Preparation of sample solution}

Twenty tablets were weighed and average weight was calculated. Then they were powdered using mortar and pestle and the powder equivalent to $20 \mathrm{mg}$ of TEN and $500 \mathrm{mg}$ of MET was accurately weighed and transferred in to a $100 \mathrm{ml}$ volumetric flask. $50 \mathrm{ml}$ of diluent was added and sonicated for $25 \mathrm{~min}$. Further the volume was made up with diluent to obtain a concentration of $200 \mu \mathrm{g} / \mathrm{ml}$ for TEN and $5000 \mu \mathrm{g} / \mathrm{ml}$ for MET. Filters of 0.45 micron size were employed for filtration purpose in the mentioned procedure. One $\mathrm{ml}$ of the above solution was pipette out and transferred into a $10 \mathrm{~m}$ volumetric flask and diluted up to the mark with diluents to obtain a concentration of $20 \mu \mathrm{g} / \mathrm{ml}$ for TEN and $500 \mu \mathrm{g} / \mathrm{ml}$ for MET.

\section{Preparation of buffer}

One $\mathrm{ml}$ of ortho phosphoric acid was diluted to $100 \mathrm{ml}$ with HPLC grade water to obtain $0.1 \%$ ortho phosphoric acid buffer.

\section{Mobile phase}

Buffer, acetonitrile and methanol were taken in the ratio of $65: 25: 10, \mathrm{v} / \mathrm{v} / \mathrm{v}$ and was used as mobile phase. 


\section{Method Validation}

Method validation was done as per the guidelines of $\mathrm{ICH}^{30,31 .}$

\section{System suitability}

System performance parameters like retention time, number of theoretical plates, tailing factor, resolution were calculated by injecting standard solutions for six times. The resultant results were compared with the standard limits as per guidelines.

\section{Specificity}

It is the ability of a method to discriminate between the analyte of interest and other components that are present in the sample. These studies are to check the interferences in the optimized method. To assess the method specificity, blank and placebo were injected into HPLC system under optimized conditions. There should not be any interfering peak in the blank or placebo chromatograms at the retention times of the selected drugs

\section{Linearity}

The linearity of the method was obtained by preparation of the calibration standards of six different concentrations in 6 replicates. The calibration curve plots for TEN \& MET were obtained by plotting the peaks areas on y-axis and concentrations on $x$-axis over the concentration ranges of 5-30 $\mu \mathrm{g} / \mathrm{ml}$ for TEN and $125-750 \mu \mathrm{g} / \mathrm{ml}$ for MET. The correlation coefficient should be greater than 0.99 .

\section{Accuracy}

The accuracy of the method was assessed by recovery experiments by adding a known quantity of pure standard drug into the sample solution and recovering the same in terms of its peak areas. The sample was spiked with standard at levels of $50 \%, 100 \%$ and $150 \%$ of test concentrations. 
The resultant spiked sample was assayed in triplicate. The \%recovery for each level should be in between $98 \%-102 \%$.

\section{Precision}

It is the degree of closeness of agreement between the series of measurements obtained from multiple sampling of the same homogenous sample under prescribed conditions. It is expressed in terms of standard deviation (SD) or relative standard deviation (RSD). Precision may be measure of either degree of repeatability or reproducibility of the analytical method

Method precision: Sample solutions were injected under optimized conditions for six times on six different days and their peak areas were recorded. \%RSD for the peak areas of 6 standard injection results should not be greater than 2 .

Intermediate precision: Six replicates of sample solutions were injected under optimized conditions on the same day and their peak areas were recorded. \%RSD for the peak areas of 6 replicate injection results should not be greater than 2 .

\section{Ruggedness}

The ruggedness of the method was determined by carrying out the experiment on different instruments, by different operators and using different columns of similar types.

\section{Robustness}

The robustness of the method was determined by making small deliberate changes in the method like flow rate, mobile phase ratio \& temperature. But, one should not find remarkable change in the results and the obtained results should be within range as per ICH guidelines.

Effect of variation of flow: Sample was analyzed at $0.9 \mathrm{ml} / \mathrm{min} \& 1.1 \mathrm{ml} / \mathrm{min}$ flow rate instead of $1.0 \mathrm{ml} / \mathrm{min}$, remaining conditions are kept constant. 
Effect of variation of temperature: Temperature of $25^{\circ} \mathrm{C}$ and $35^{\circ} \mathrm{C}$ was maintained instead of $30^{\circ} \mathrm{C}$. Samples were injected in triplicate \& chromatograms were recorded.

\section{LOD \& LOQ}

LOD is the smallest concentration that can be detected but not necessarily be quantified as an exact value. It is calculated using formula

$$
\mathrm{LOD}=3.3 \sigma / \mathrm{S} ; \text { where, } \sigma=\mathrm{S} . \mathrm{D} ; \mathrm{S}=\text { Slope }
$$

LOQ is the lowest amount of analyte in the sample that can be quantitatively determined with precision \& accuracy.

$$
\text { LOQ }=10 \sigma / S ; \text { where, } \sigma=\text { S.D; } S=\text { Slope }
$$

\section{Forced Degradation Studies}

TEN \& MET standard samples were subjected to degradation under different stress conditions like acidic, alkali, oxidative, thermal, photo stability and neutral conditions.

For acidic \& alkali degradation samples were refluxed with $2 \mathrm{~N} \mathrm{HCl} \& 2 \mathrm{~N} \mathrm{NaOH}$ at $60^{\circ} \mathrm{C}$ for 30 min. For oxidative degradation $20 \% \mathrm{v} / \mathrm{v}, \mathrm{H}_{2} \mathrm{O}_{2}$ was used and the same was refluxed at $60^{\circ} \mathrm{C}$ for $30 \mathrm{~min}$. For thermal degradation, sample was placed in oven at $105^{\circ} \mathrm{C}$ for $6 \mathrm{hr}$; and for photo stability degradation, drug was exposed to UV light by keeping the sample in UV chamber for 7 days or 200 watt hours $/ \mathrm{m}^{2}$ in photo stability chamber; for neutral degradation, the drugs were refluxed in water for 6 hours at a temperature of $60^{\circ} \mathrm{C}$. All the samples were diluted to obtain a final concentration of $20 \mu \mathrm{g} / \mathrm{ml}$ of TEN \& $500 \mu \mathrm{g} / \mathrm{ml}$ of MET. Ten micro liters of the samples were injected into the system and the chromatograms were recorded to assess the stability of the sample.

\section{Solution Stability}


The stability of the drug solution was determined for the short term stability, auto sampler stability. Short term stability was carried out by keeping the samples, at room temp $\left(25^{\circ} \mathrm{C}\right)$ for 24 hrs. Auto sampler stability was determined by storing the samples for $24 \mathrm{hrs}$ in the auto sampler. Each sample was injected 6 times into HPLC \& the results obtained were compared with nominal values of QC samples.

\section{RESULTS}

The results of optimized chromatographic conditions were shown in Table 1. System suitability parameters (tailing factor, retention time \& theoretical plates) were found to be within acceptance criteria. Summary of system suitability parameters were tabulated in Table 2 . We did not find any interfering peaks at the retention times of TEN \& MET (Fig. 3), which declares that the method is specific. The quantification was linear in the concentration range of $5-30 \mu \mathrm{g} / \mathrm{ml}$ for TEN with a correlation coefficient 0.999 (Fig. 4); 125-750 $\mu \mathrm{g} / \mathrm{ml}$ for MET with a correlation coefficient 0.999 (Fig. 5) respectively. The results of linearity were tabulated in Table 3. The recoveries of TEN and MET were found to be in the range of $99.35-99.94 \%$ and $99.80-100.61 \%$ respectively. The results were compared with the guidelines $\&$ expressed as percentages and the results were given in Tabie 4 . The precision of the method is satisfactory as \%RSD is NMT $2 \%$. The ruggedness was performed by different analyst $\&$ on different days. The results were given in Table 5. No remarkable changes in the results were notice in robustness studies and hence the method is robust. The results were tabulated in Table 6 . The assay results were compared with the labeled claim of TEN \& MET marketed formulation and the results were tabulated in Table 7. The LOD \& LOQ values were calculated using slope and standard deviation values and the same were tabulated in Table 8.

\section{Forced degradation study}


The standard solutions were subjected to different stress conditions as mentioned in the procedure. Under acidic conditions, drugs showed degradation of about $3.66 \%$ for TEN \& $3.14 \%$ for MET and we have noticed about 3 degradation peaks (Fig. 6). Under alkali conditions, drugs showed degradation of about $2.75 \%$ for TEN \& $2.67 \%$ for MET and 2 degradation peaks were noticed (Fig. 7). Under oxidative conditions, drugs showed degradation of about $1.01 \%$ for TEN \& $1.62 \%$ for MET and 1 degradation peak was noticed (Fig. 8). Under remaining conditions, thermal, photo stability and neutral conditions, the degradation was less than $1 \%$ for both the drugs and no degradant peak was noticed (Fig. 9-11). Result of forced degradation studies are tabulated in Table 9.

\section{Stability studies}

The drug solutions were found to be stable for $24 \mathrm{hrs}$ at $25^{\circ} \mathrm{C}$ for short term stability and $24 \mathrm{hrs}$ for auto sampler stability.

\section{DISCUSSION}

For method optimization different ratios of acetonitrile \& buffer were tried but, resolution of peak was not achieved. Hence, methanol was used in mobile phase. Different ratios of ortho phosphoric acid buffer, methanol were tried i.e., 65:15:20, v/v/v, 60:20:20, v/v/v, 65:20:15, v/v/v. Finally, it was found that buffer:acetonitrile:methanol in the ratio of $65: 25: 10, \mathrm{v} / \mathrm{v} / \mathrm{v}$, gave good peaks and hence fixed as mobile phase. Kromasil C18 (250 X $4.6 \mathrm{~mm}, 5 \mu \mathrm{m})$ column, 1 $\mathrm{ml} / \mathrm{min}$ flow rate, $10 \mu \mathrm{l}$ injection volume, $30^{\circ} \mathrm{C}$ column oven temperature, $254 \mathrm{~nm}$ wave length were fixed as optimized conditions which were found to be suitable for the separation of peaks. These optimized conditions gave a retention time of $2.842 \mathrm{~min}$ and $2.017 \mathrm{~min}$ for TEN \& MET. Ali the validation results were as per the limits of $\mathrm{ICH}$ and hence, found to be a reliable and economical method for the estimation of drugs. The effectiveness of the method to separate the 
degraded peaks from analyte shows its stability indicating nature. The degradation on the lower side i.e., the degradation percent under all conditions is in the range of $0.05 \%$ to $3.66 \%$ shows the stability of the selected drugs. The \%RSD values were found to be less than 2 .

\section{CONCLUSION}

The developed method posses all the qualities to be a reliable, rapid, sensitive, specific and economical method from the above discussed results and data. The study showed stability indicating nature of the method with the possible short runtime. Hence, the developed method could be conveniently and effectively used for routine simultaneous estimation of Teniligliptin and Metformin in bulk and pharmaceutical dosage form. 


\section{References:}

1. Yoshida T, Akhashi F, Sakashita H. Discovery and preclinical profile of Teneligliptin. Bioorg Med Chem., 2012; 20: 5705-5719.

2. Kishimoto M. Teneligliptin: A DPP-4 inhibitor for the treatment of type 2 diabetes. Diabetes, Metabolic Syndrome and Obesity: Targets and Therapy, 2013; 6:187- 95.

3. Indian Pharmacopoeia, Government of India, Ministry of Health \& Family Weifare, Volume-2, Ghaziabad, the Indian Pharmacopoeia Commission, 2007; 1358-59.

4. The Merck Index, Merck \& Co Inc, White House Station,New Jersey, USA, 13th Editi on, 2001,1061.

5. Martindale, The complete drug reference. 36th Edition. Vol. I. London (UK): Pharmaceutical Press (An Imprint of RPS Publishing); 2009. 453-54.

6. Amit MS, Kiran KD, Varsha AR. A simple UV Spectrophotometric method development and validation of teneligliptin in tablet dosage form. Indo Am J Pharm Res., 2016; 6(04): $14-21$.

7. Manjusha DK, Barhate VD. Spectrophotometric determination of an anti diabetic drug Teneligliptin bulk and pharmaceutical formulations. W J Pharm Res., 2016; 5(5): 1625 1632.

8. Mahadik PS, Senthilkumar GP, Devprakash D, Tamiz MT, Priyanka KG, Sulbha AG. Method development and validation of Metformin in bulk and pharmaceutical dosage forms by using spectrophotometric Method. Am J Pharmtech Res., 2012; 2(1):56-61.

9. Atul TH, Rathod EA, Gupta KR and Umekar MJ: HPLC and UV-spectrophotometric estimation of Teneligliptin from tablet dosage form. Asian Journal of Pharmaceutical Analysis and Medicinal Chemistry 2016; 4(3): 148- 156. 
10. Ganeshkumar TNV, Vidyadhara S, Niteen AN, Saisilpa Y, Rajyalakshmi M. Method development, validation, and stability studies of teneligliptin by RP-HPLC and identification of degradation products by UPLC tandem mass spectroscopy. J Anal Sci Tech., 2016; 7: 18-23.

11. Chandana M, Prasad Rao M, Samrajyam B, Sireesha KSKD, Naga premi VV. Analytical method development and validation of teneligliptin in pharmaceutical dosage form by RP-HPLC method, J Heal Sci and Nur., 2016; 1(12): 1-12.

12. Atul TH, Rathod EA, Gupta KR, Umekar MJ. HPLC and UV-Spectrophotometric estimation of teneligliptin from tablet dosage form. As I Pharm Anal and Med Chem., $2016 ; 4(3): 148-156$.

13. Sowjanya P. RP-HPLC Method Development of Metformin in Pharmaceutical Dosage Form Research and Reviews. J Pharm Anal., 2015; 4(4): 2347-2340.

14. Madhukar A, Prince A, Vijay Kumar R, Sanjeeva Y, Jagadeeshwar K, Raghupratap D. Simple and sensitive analytical method development and validation of Metformin Hydrochloride by RP-HPLC Int J Pharm and Pharml Sci., 2011; 3(3): 117-120.

15. AliSaad AA, Mukkanti K and Chandrashekar K: Analytical method development and method validation of metformin hydrochloride and pioglitazone hydrochloride in bulk and their pharmaceutical dosage forms by RP-HPLC. Anal Chem: An Indian J., 2011; 10(12): $771-775$.

16. Murthy TGK, Geethanjali J. Development of a validated RP-HPLC method for simultaneous estimation of metformin hydrochloride and rosuvastatin calcium in bulk and in-house formulation. Chrom Sep Tech., 2014; 5(6): 1-7. 
17. Neelima K, Prasad RY. Analytical method development and validation of metformin, voglibose, glimepiride in bulk and combined tablet dosage form by gradient RP-HPLC. Pharm Met., 2014; 5(1): 27-33.

18. Prasad PB, Satyanaryana K, Krishnamohan G. Development and validation of a method for simultaneous determination of metformin and saxagliptin in a formulation by $R P$ HPLC. Amer J Anal Chem., 2015; 6: 841-850.

19. Shailesh VL, Kamna RP, Jani GK and Sachin BN: Simultaneous estimation of teneligliptin hydrobromide hydrate and its degradation product by RP-HPLC method. J Pharm Sci and Biosci Res., 2016; 6(3): 254-261.

20. Shinde VC, Aher KB, Bhavar GB, Kakad SJ, Chaudhari SR. Development and validation of UV spectrophotometric method and high performance thin layer chromatographic (HPTLC) method for estimation of teneligliptin hydrobromide in pharmaceutical preparation. Der Pharm Lett., 2016;8(8):291-301.

21. Chunduri RHB, Dannana GS. Development and validation of LC-MS/MS method for quantification of teneligliptin in human plasma and its application to a pharmacokinetic study. W J Pharm and Pharm Sci., 2016; 5(5):833-50.

22. Ashim KS, Denish NH, Dhanya BS, Aarti SZ, Rajesh AM, Vikas RC. Analytical method development and validation for simultaneous estimation of teneligliptin hydrobromide hydrate and metformin hydrochloride from its pharmaceutical dosage form by three different UV spectrophotometric methods. J App Pharm Sci., 2016; 6(09): 157-165.

Kumar AS, Denish NH, Sen DB, Aarti SJ, Rajesh AM, Vikas RC. Analytical method development and validation for simultaneous estimation of Teneligliptin hydrobromide 
hydrate and Metformin hydrochloride from its pharmaceutical dosage form by three different UV Spectrophotometer methods. J App Pharm Sci., 2016; 6(9): 157-165.

24. Joshi H, Khristi A. Absorbance ratio method development and validation for the simultaneous estimation of Teneligliptin hydrobromide hydrate and Metformin hydrochloride in Tablet Dosage Form. Int Res J Pharm., 2018; 9(1): 47-55.

25. Gopal SI et al., RP-HPLC method development and validation of teneligliptin and metformin in pharmaceutical dosage forms. Int Res J Pharm., 2017; 8(8):52-55.

26. Deepak P, Sufiyan A, Shastry VM, Tabrej M, Lalit T. Analytical method development and validation for the simultaneous estimation of metformin and teneligliptin by RPHPLC in bulk and tablet dosage forms. J Pharm Res., 2017; 11(6):676-681.

27. Manish DP, Mayank B, Priyanka S, Suleman SK Development and validation of analytical method for simultaneous estimation of metformin hydrochloride and teneligliptin hydrobromide hydrate in pharmaceutical dosage form. J Pharm Sci Bioscientific Res., 2017. 7(2):200-208.

28. Shaikh AR, Ahmed BARK, Ibrahim M. A validated stability indicating RP - HPLC method for simultaneous estimation of metformin and teneligliptin in bulk and pharmaceutical dosage form. Int J Pharm Sci Res 2018; 9(4): 1705-12.

29. Mrunal CS, Annapurna MM. Simultaneous Determination of Metformin and Teneligliptin by Liquid Chromatography in tablets. Asian J Pharmaceu., 2018; 12(2): 736-739.

30. ICH Harmonized Tripartite Guideline: Text on Validation of Analytical Procedures, Text and Methodology, Q2(R1), International Conference on Harmonization, Geneva 2005;117. 
31. ICH Harmonized Tripartite Guideline: Stability Testing of New Drug Substances and Products, Q1A(R2), International Conference on Harmonization, Geneva 2003; 1-24. 
Table 1: Optimized chromatographic conditions

\begin{tabular}{cc}
\hline Parameter & Condition \\
\hline Column & Kromasil C18 $(250 \times 4.6 \mathrm{~mm}, 5 \mu)$ \\
Mobile phase & Buffer:acetonitrile:methanol $(65: 25: 10, \mathrm{v} / \mathrm{v} / \mathrm{v})$ \\
Diluent & Acetonitrile:water $(50: 50, \mathrm{v} / \mathrm{v})$ \\
Column temperature & $30^{\circ} \mathrm{C}$ \\
Wavelength & $254 \mathrm{~nm}$ \\
Flow rate & $1 \mathrm{ml} / \mathrm{min}$ \\
Run time & $6 \mathrm{~min}$ \\
Injection volume & $10 \mu 1$ \\
\hline
\end{tabular}

Table 2: Summary of system suitability parameters

\begin{tabular}{cccc}
\hline Parameter & TEN & MET & Acceptance criteria \\
\hline Tailing factor & 1.30 & 1.06 & $\leq 2$ \\
Retention time & 2.842 & 2.017 & $\geq 2$ \\
Theoretical plates & 4463 & 6783 & $\geq 2000$ \\
\%RSD of area & 0.72 & 1.08 & $\leq 2$ \\
\hline
\end{tabular}

Table 3: Linearity values of TEN and MET

\begin{tabular}{lcc}
\hline Parameter & TEN & MET \\
\hline Linearity range $(\mu \mathrm{g} / \mathrm{ml})$ & $5-30$ & $125-750$ \\
Regression coefficient $\pm \mathrm{SD}$ & $0.999 \pm 0.0003$ & $0.999 \pm 0.0005$ \\
slope \pm SD & $8891 \pm 4.358$ & $4665 \pm 8.386$ \\
Intercept \pm SD & $1773 \pm 58.66$ & $35915 \pm 2654.363$
\end{tabular}


Table 4: Recovery values of TEN and MET

\begin{tabular}{|c|c|c|c|c|c|}
\hline Drug & Level & $\begin{array}{c}\text { Analyte } \\
\text { amount (mg) }\end{array}$ & $\begin{array}{c}\text { Recovery } \\
\text { amount (mg) }\end{array}$ & $\begin{array}{l}\text { Mean \% } \\
\text { recovery }\end{array}$ & \%RSD \\
\hline \multirow{3}{*}{ TEN } & $50 \%$ & 10 & 9.94 & 99.43 & 0.20 \\
\hline & $100 \%$ & 20 & 19.98 & 99.91 & 0.60 \\
\hline & $150 \%$ & 30 & 29.97 & 99.92 & 0.67 \\
\hline \multirow{3}{*}{ MET } & $50 \%$ & 250 & 249.50 & 99.80 & 0.90 \\
\hline & $100 \%$ & 500 & 503.07 & 100.61 & 0.40 \\
\hline & $150 \%$ & 750 & 752.82 & 100.37 & 0.50 \\
\hline
\end{tabular}

Table 5: Ruggedness values of TEN and MET

\begin{tabular}{ccccc}
\hline Drug & $\begin{array}{c}\text { Analysts-1 } \\
\text { (Peak area)* }\end{array}$ & Analyst-2 & SD & \%RSD \\
& (Peak area)* & & \\
\hline TEN & 172792 & 173167 & 1248 & 0.72 \\
MET & 2363854 & 2320575 & 12026 & 0.50 \\
\hline
\end{tabular}

*Average of six readings 
Table 6: Robustness values of TEN and MET

\begin{tabular}{lcccccc}
\hline Condition & \multicolumn{3}{c}{ TEN } & & \multicolumn{3}{c}{ MET } \\
& Retention & Area & Tailing & Retention & Area & Tailing \\
& time & & factor & time & & factor \\
& 2.837 & 268209 & 1.14 & 2.027 & 3521349 & 0.98 \\
\hline Initial conditions & 2.827 & 269207 & 1.13 & 2.012 & 3540846 & 0.95 \\
More flow $(+0.1 \mathrm{ml} / \mathrm{min})$ & 2.851 & 267902 & 1.10 & 2.041 & 3536801 & 1.00 \\
Less flow $(-0.1 \mathrm{ml} / \mathrm{min})$ & 2.841 & 267189 & 1.13 & 2.028 & 3520932 & 0.99 \\
At $35^{\circ} \mathrm{C}$ & 2.840 & 269218 & 1.09 & 2.029 & 3519867 & 1.11 \\
At $25^{\circ} \mathrm{C}$ & & & & & & \\
\hline
\end{tabular}

Table 7: Assay results of marketed formulacion (Tendia M tablets)

\begin{tabular}{|c|c|c|c|}
\hline Drug & Label claim & Amount found & \%Assay \\
\hline TEN & $20 \mathrm{mg}$ & $19.98 \mathrm{mg}$ & 99.90 \\
\hline MET & & $498.85 \mathrm{mg}$ & 99.77 \\
\hline
\end{tabular}

Table 8: LOD \& LOQ values of TEN \& MET

\begin{tabular}{ccc}
\hline Drug & LOD $(\boldsymbol{\mu g} / \mathbf{m l})$ & LOQ $(\boldsymbol{\mu g} / \mathbf{m l})$ \\
\hline TEN & 0.02 & 0.07 \\
MET & 1.88 & 5.69 \\
\hline
\end{tabular}


Table 9: Forced degradation data* $( \pm$ SD $)$ of the method

\begin{tabular}{|c|c|c|c|c|}
\hline $\begin{array}{l}\text { Stress } \\
\text { condition }\end{array}$ & $\begin{array}{l}\text { Amount of TEN } \\
\text { degraded (\%) }\end{array}$ & $\begin{array}{l}\text { Amount of TEN } \\
\text { recovered (\%) }\end{array}$ & $\begin{array}{l}\text { Amount of MET } \\
\text { degraded (\%) }\end{array}$ & $\begin{array}{l}\text { Amount of MET } \\
\text { recovered }(\%)\end{array}$ \\
\hline Acidic & $3.67 \pm 0.89$ & $96.33 \pm 3.12$ & $3.15 \pm 0.62$ & $96.85 \pm 2.19$ \\
\hline Alkali & $2.76 \pm 0.58$ & $97.24 \pm 2.98$ & $2.68 \pm 0.85$ & $97.32 \pm 2.81$ \\
\hline Oxidative & $1.02 \pm 0.69$ & $98.98 \pm 1.98$ & $1.63 \pm 0.98$ & \\
\hline Thermal & $0.75 \pm 0.08$ & $99.25 \pm 1.87$ & $0.62 \pm 0.10$ & $.38 \pm 0.91$ \\
\hline Photo stability & $0.63 \pm 0.06$ & $99.37 \pm 1.39$ & $0.59 \pm 0.09$ & $99.41 \pm 1.92$ \\
\hline Neutral & $0.53 \pm 0.08$ & $99.47 \pm 2.01$ & $0.05 \pm 0.08$ & $99.95 \pm 1.79$ \\
\hline
\end{tabular}

*Average of three determinations (each condition); SD;Standard deviation 


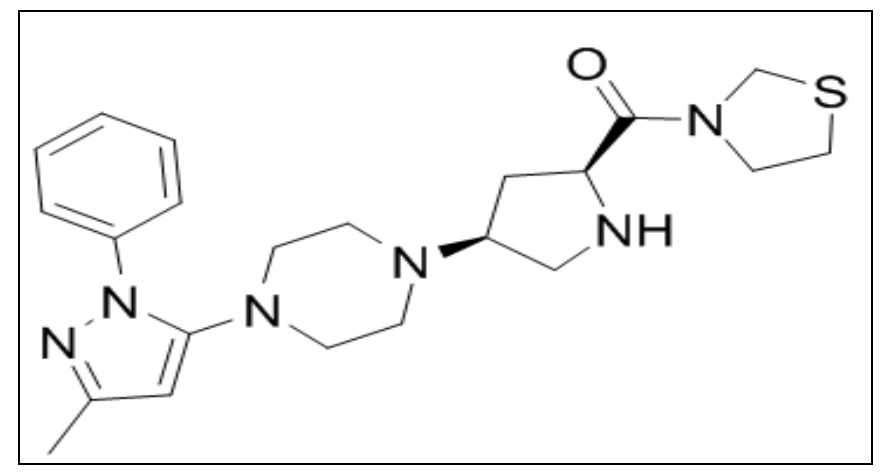

Figure 1: Chemical structure of TEN

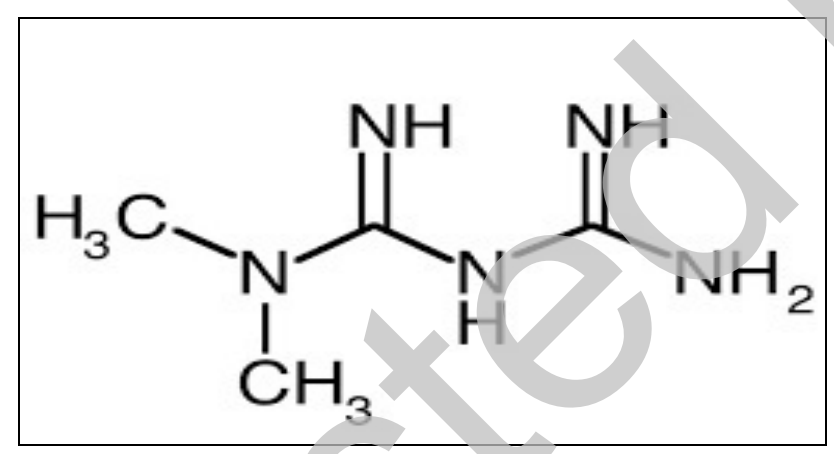

Figure 2: Chemical structure of MET

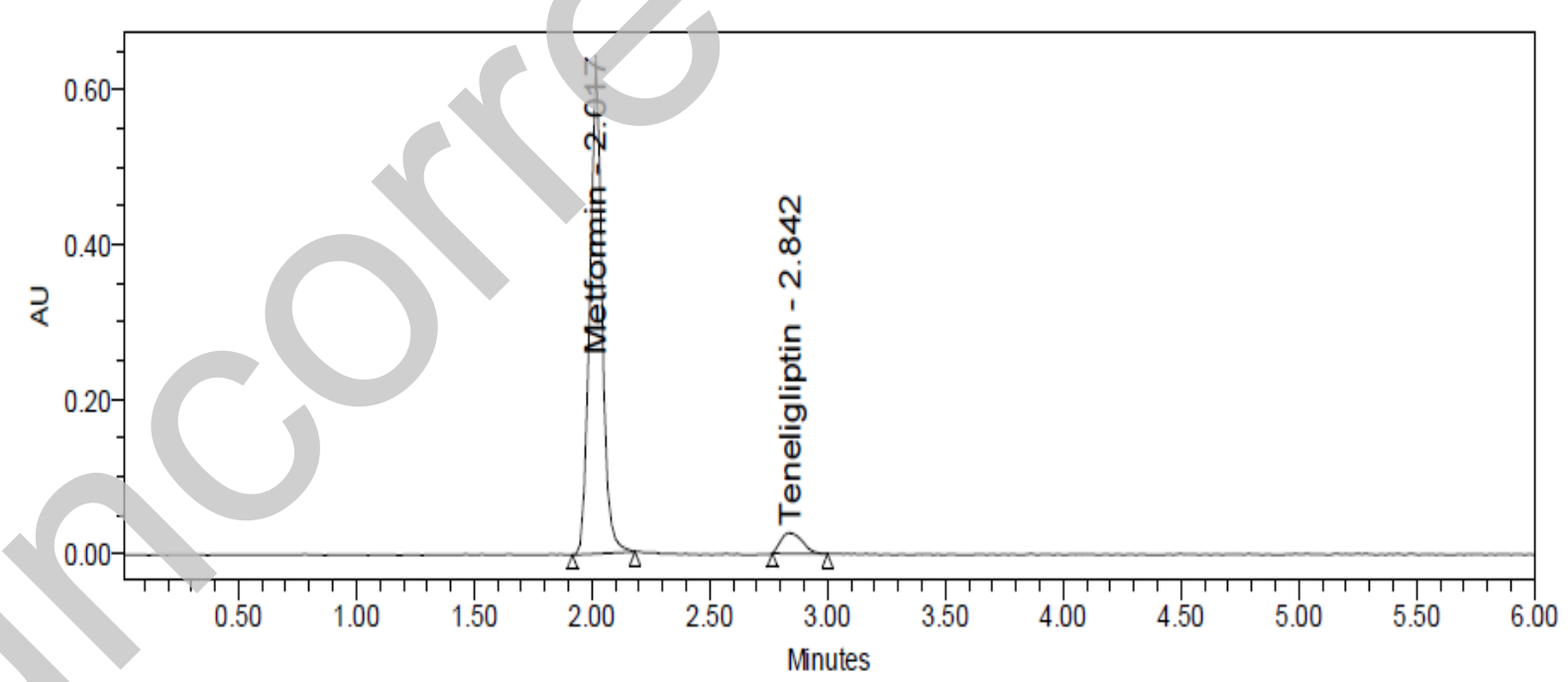

Figure 3: Chromatogram showing resolved peaks of TEN and MET 


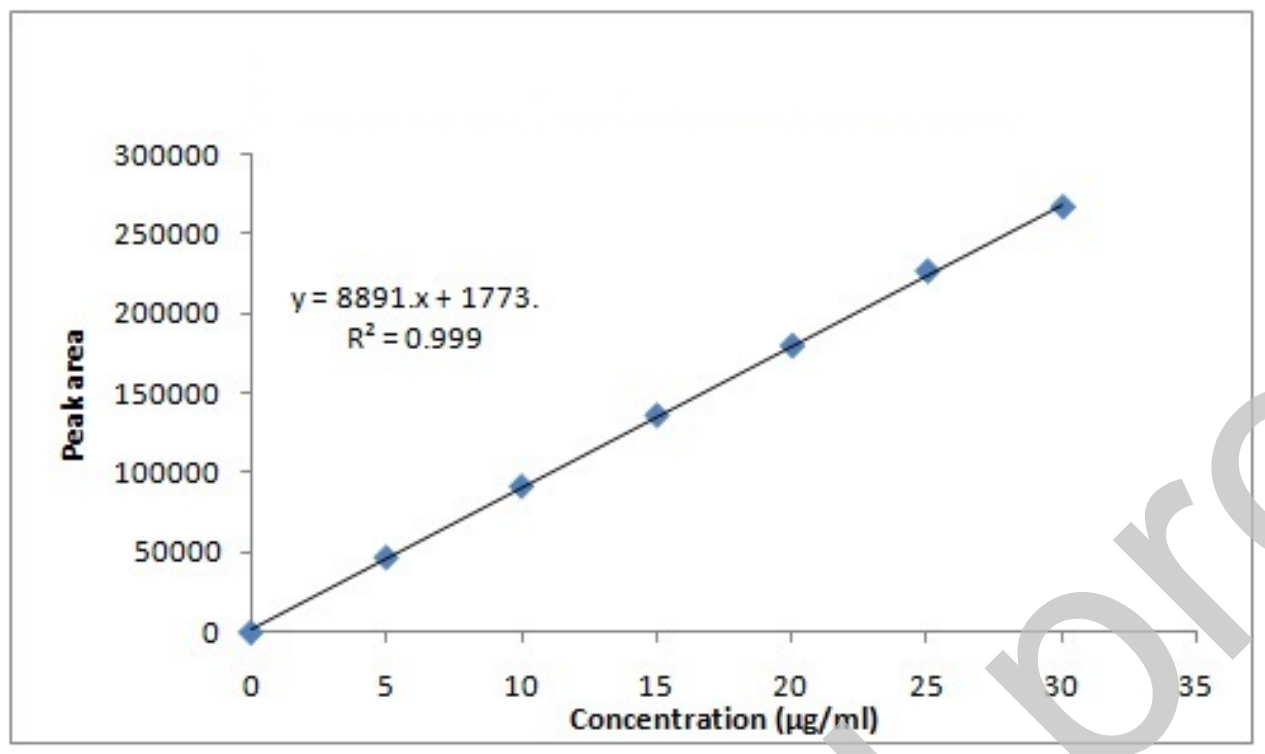

Figure 4: Linearity plot of TEN

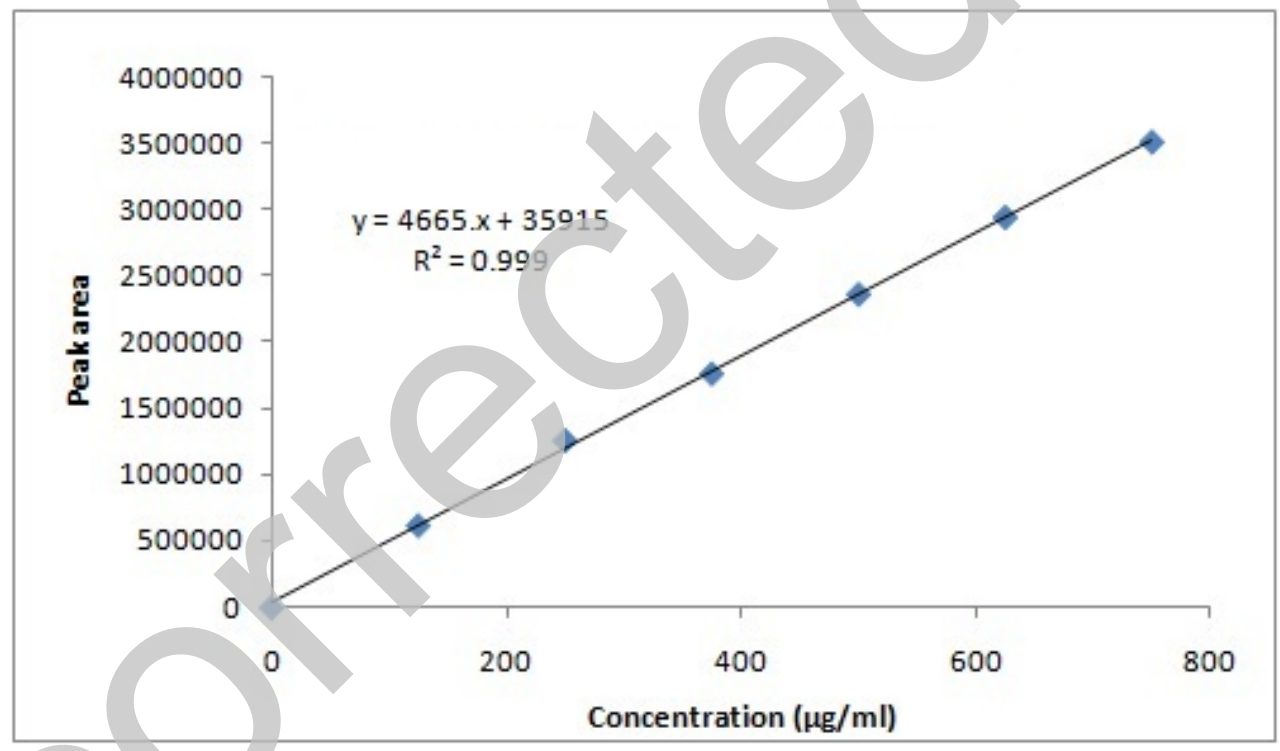

Figure 5: Linearity plot of MET 


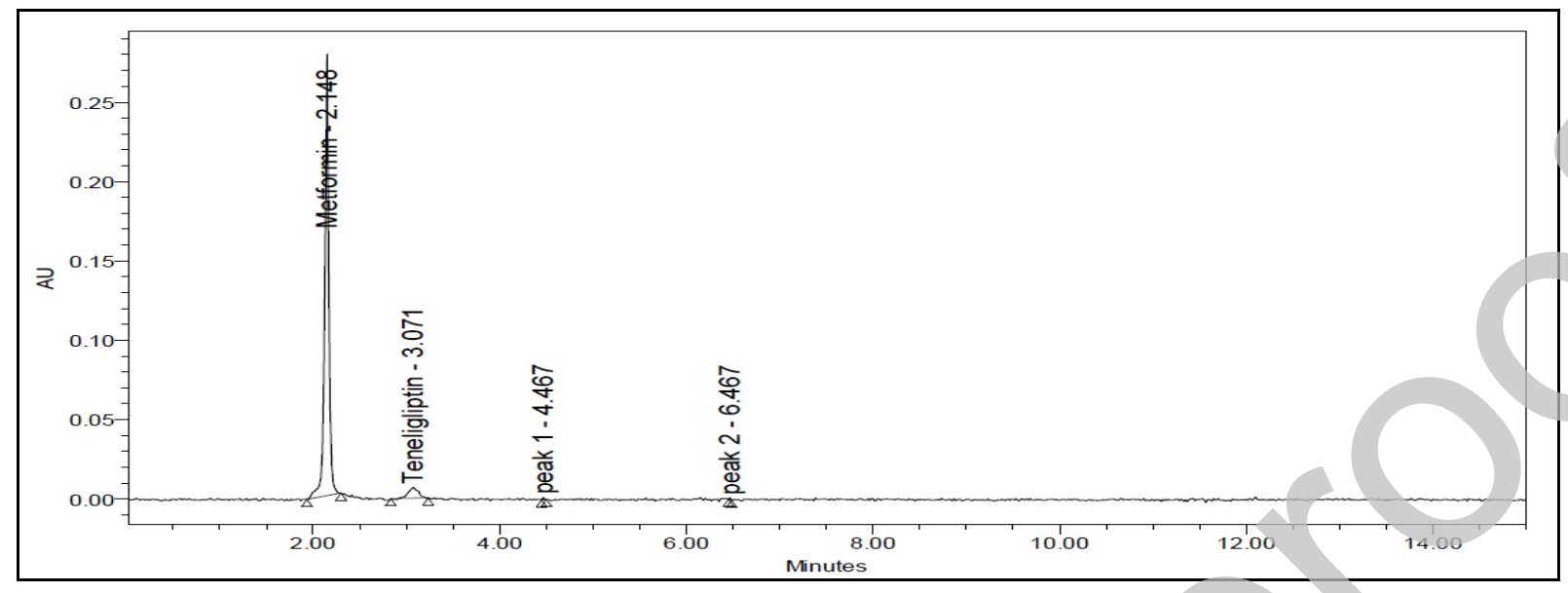

Figure 6: Chromatogram showing degraded peaks under acidic conditions

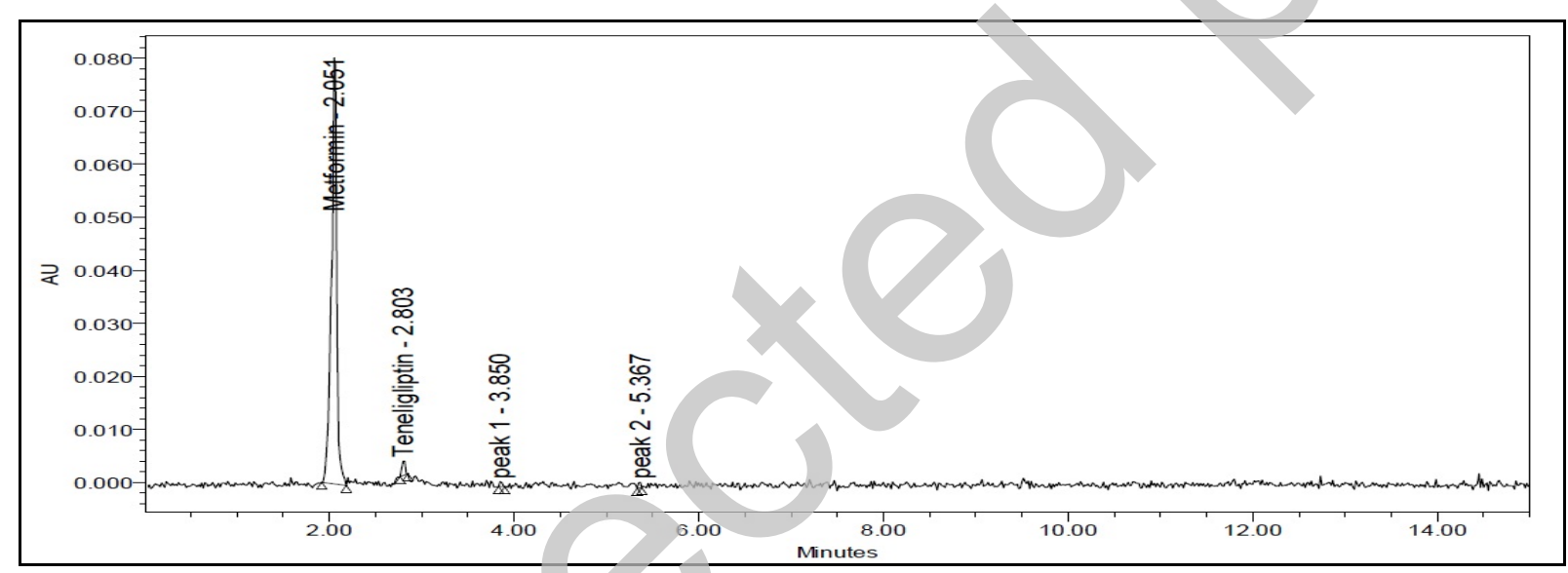

Figure 7: Chromatogram showing degraded peaks under alkali conditions

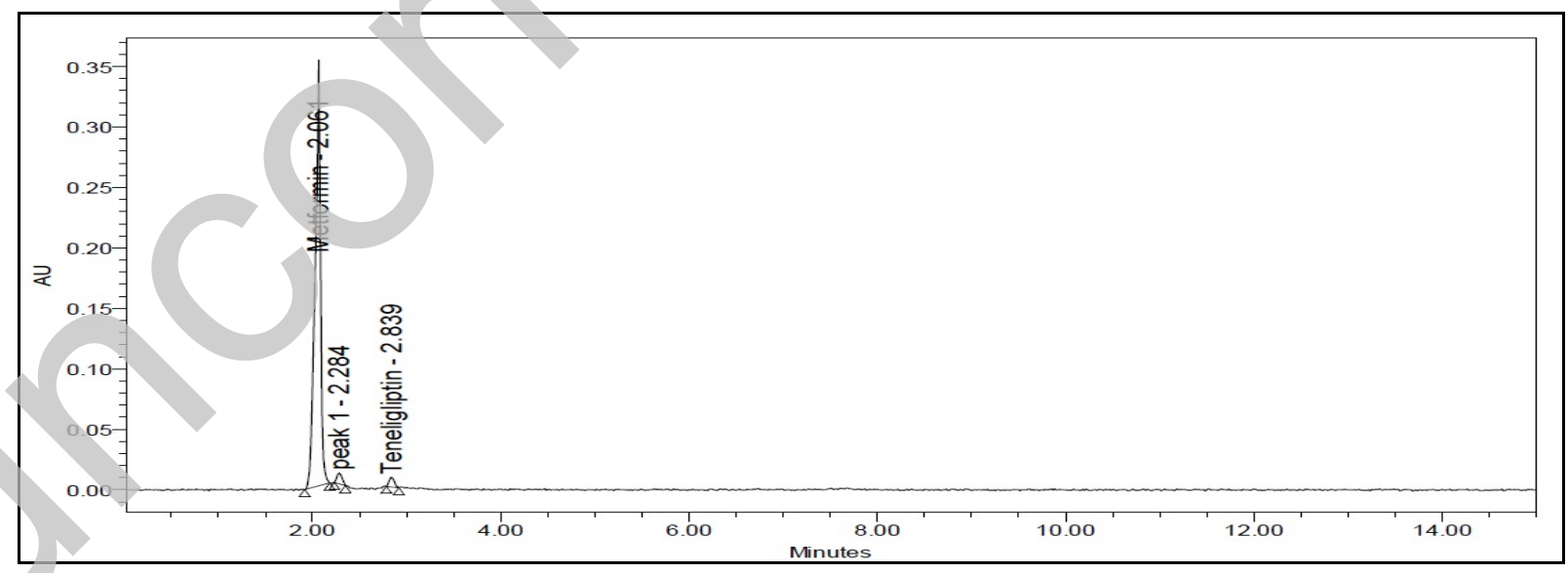

Figure 8: Chromatogram showing degraded peaks under oxidative conditions 


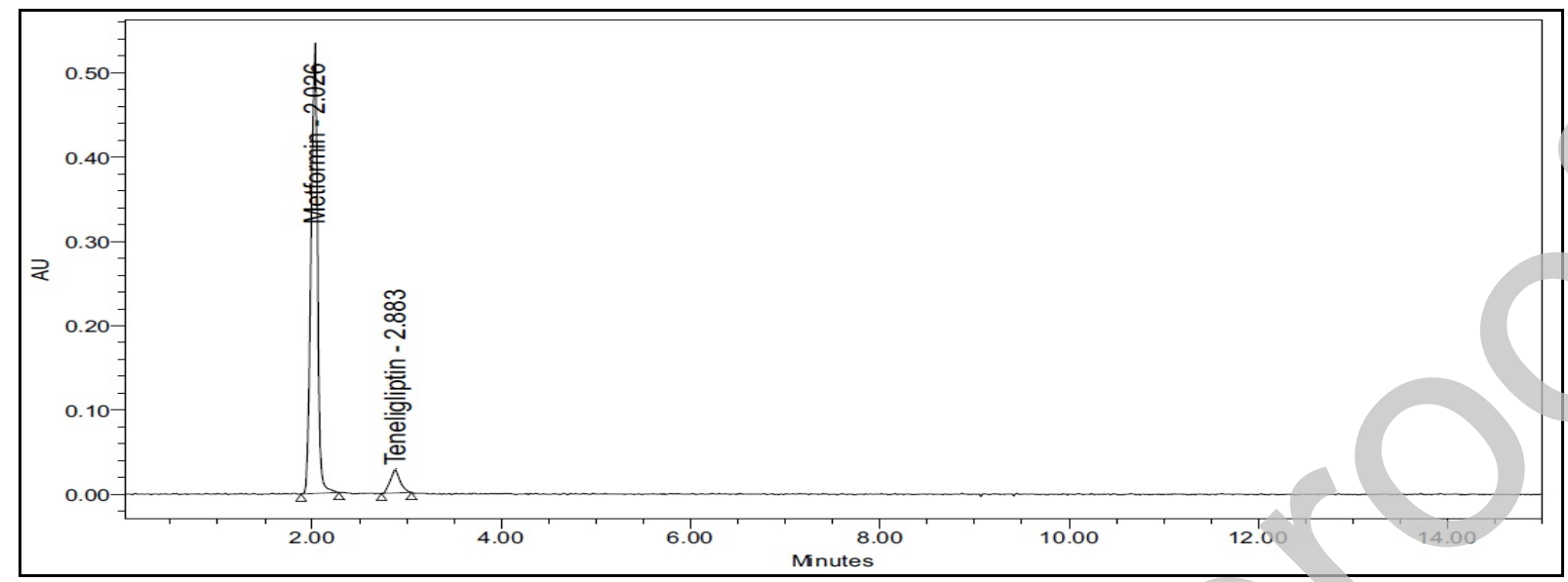

Figure 9: Chromatogram showing degraded peaks under thermal conditions

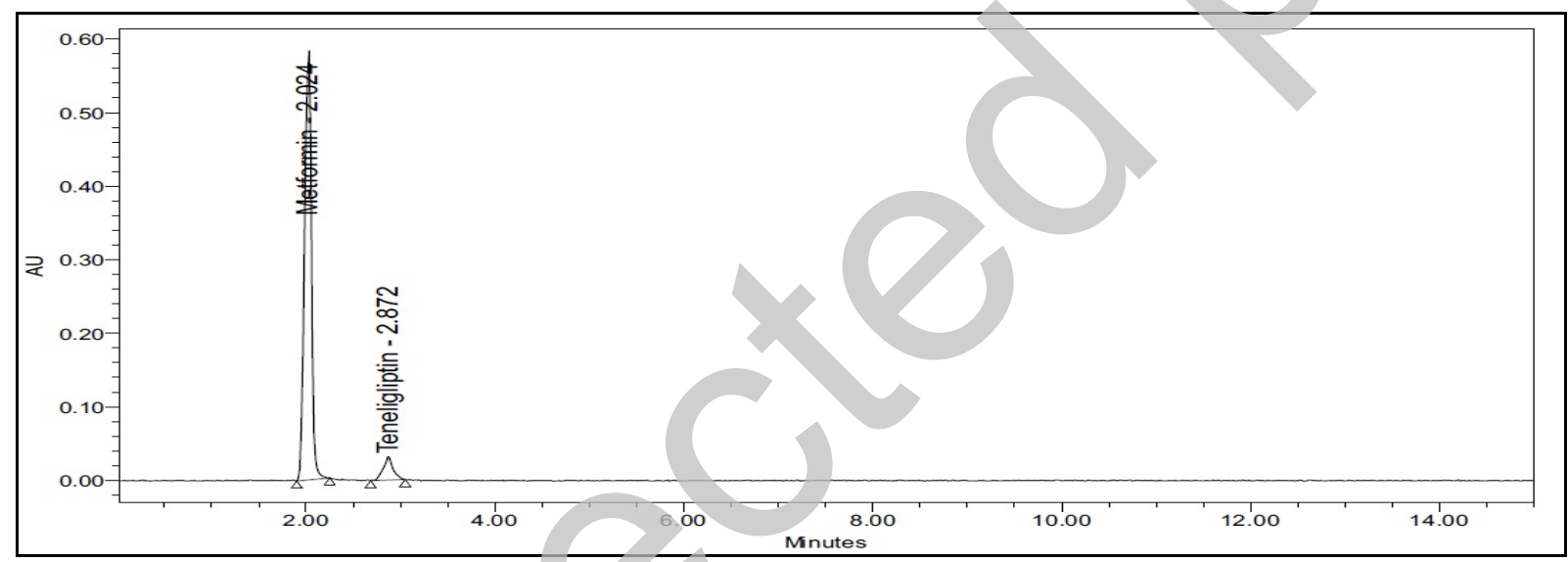

Figure 10: Chromatogram showing degraded peaks under photo stability conditions

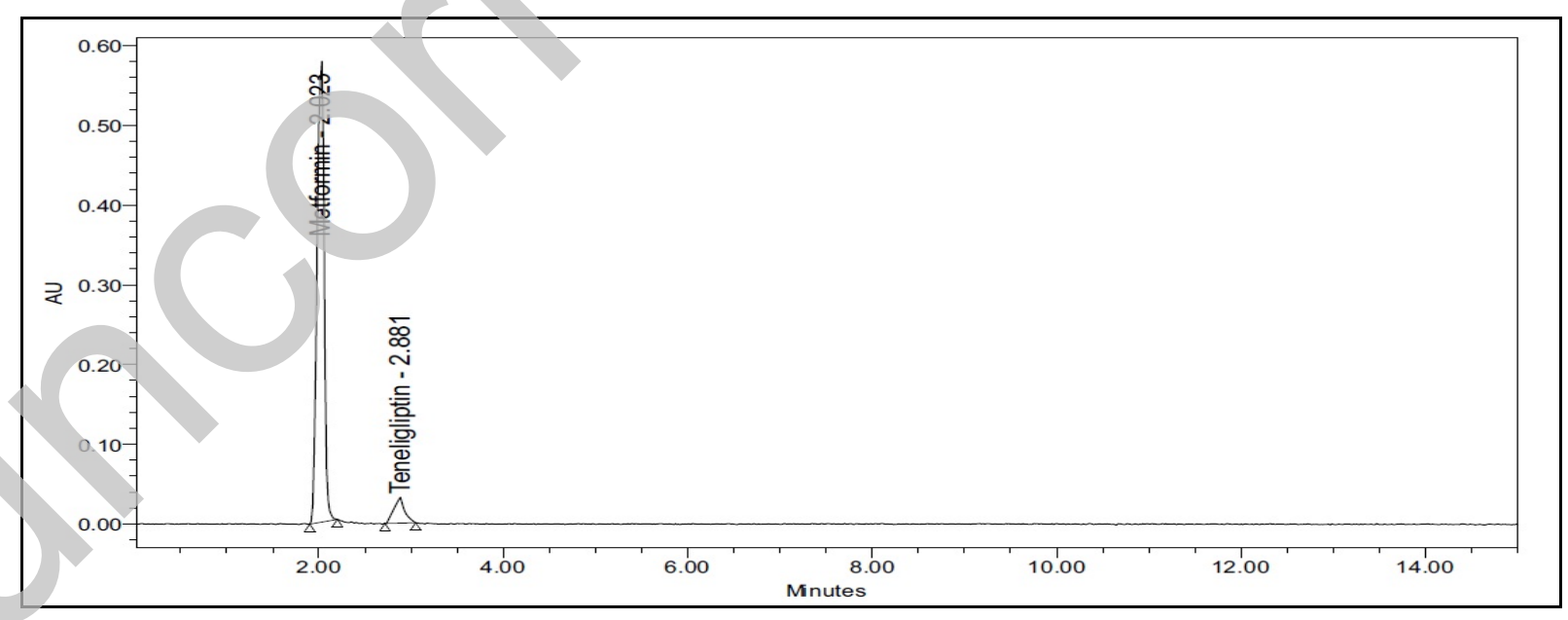

Figure 11: Chromatogram showing degraded peaks under neutral conditions 